\title{
On Stage Māori-Medium ITE: Listening to Students' Voices
}

\author{
Jenny Lee-Morgan and Maureen Muller \\ Te Kotahi Research Institute, The University of Waikato
}

\begin{abstract}
Māori-medium initial teacher education (ITE) is a small but highly important group 'on stage' in te ao Māori and New Zealand education. While education plays a major role in Māori language revitalisation, Māori language is also pivotal to Māori education if the aspiration 'to live as Māori' (Durie, 2001) is to be fulfilled. Māori-medium teachers are critical to the success of learners and their whānau who select a Māori-medium pathway and who can make a meaningful difference to the educational outcomes of Māori (Hōhepa, Hāwea, Tamatea, \& Heaton, 2014). This article draws on the students' voices in a two-year research project that centered on the development of a teaching and learning initiative within one Māori-medium ITE programme. Building on previous work by Hōhepa et al. (2014), this study adds another layer of students' voices to understand more clearly language related issues and student experiences in Māori-medium ITE programmes. The article presents some of the complexities associated with Māori language regeneration facing students of Māori-medium ITE, with the understanding that whatever appears on the stage is always part of a greater narrative behind the scenes.
\end{abstract}

Keywords: Māori medium education; Initial teacher education; Māori language learning; Māori education

\section{Introduction}

Inspired by the 2017 Te Matatini, the bi-annual national Māori performing arts competition that brought together, in early March, the best kapa haka groups from throughout the country, we gather our thoughts to write this article. Te Matatini was a huge three-day event held in Napier this year, but fully accessible now through digital media; it is impossible to pull oneself away from the power of the performances on the stage that showcased the best of Māori language and culture through song, dance and haka.

Watching this highly coveted event serves as a point of reflection on the Māorimedium ITE sector, a small but highly important group on stage in te ao Māori and New Zealand education. Māori-medium teachers are critical to the success of learners and their whānau who select a Māori-medium pathway, and these teachers can make a meaningful difference to the educational outcomes of Māori (Hōhepa, Hāwea, Tamatea, \& Heaton, 2014). However, Māori-medium ITE, like ITE for Indigenous communities working with their heritage languages, is under-researched (May \& Hill, 2005; Skerrett, 2011) and often in the backdrop.

Māori-medium education, including Te Kōhanga Reo, Kura Kaupapa Māori and Wharekura, evolved out of, and is part of an ongoing movement of cultural and linguistic regeneration, with te reo Māori holding centre stage. Periodically in the spotlight, the ongoing debate about whether te reo Māori should be compulsory in schools has recently re-surfaced in the election year policy debates.Both Māori language and education often draw attention to the production of reviews and initiatives, and associated policies and strategies such as Tau Mai te Reo (Ministry of Education, 2013b) and The Māori Language Strategy (Te Puni Kōkiri, 2014). Lesser known is the Māori-medium ITE sector, a significant player in teacher supply to 
Māori-medium educational settings. With the government's current policy a-preoccupation on student achievement outcomes in education, and on increasing the usage of Māori language by all New Zealanders, Māori-medium ITE can easily go unnoticed. Māori-medium ITE is itself a complex and variable site of engagement (Skerrett, 2011).

Currently, there are nine Māori-medium ITE providers delivering Māori-medium (primary) teacher programmes throughout the country, four at universities, three at whare wānanga, and two at private training establishments. All the programmes deliver a Bachelor's degree qualification, eight being three years in duration and one four years. Between 2011 and 2015 the total number of graduate completions in Māori-medium ITE (primary) programmes was 820 (W. Smart, personal communication, March 21, 2017). ${ }^{1}$ These graduates proceed to service the Māori-medium education sector defined by the Ministry of Education (2013a) as settings where teaching occurs in the Māori language for 50-100 per cent of the time. As at July 2016 there were a total of 18,444 students from 279 schools enrolled in Māori-medium education, an increase of 11\% since 2011. Of these schools, 107 delivered all subjects in Māori medium; 128 also offered Māori language in English medium (Education Counts, 2016). The official descriptor of Māori-medium ITE is also broad, and includes programmes with at least $51 \%$ Māori language. In turn, providers and programmes, delivered through either college-based or distance education, offer varied percentages of content through the Māori language, and differing ITE curriculum and programmes (Murphy, McKinley, \& Bright, 2008). ${ }^{2}$ A relatively recent development, Māori-medium ITE is challenged by a myriad of factors, including: a shortage of high quality teaching and resources; difficulty recruiting and retaining both students and high quality staff; variability in the structure, content and quality of its programmes; and variability in te reo Māori proficiency across its students, even within the same cohort (Hōhepa et al., 2014).

This article draws on a two-year project that centred on the development of a teaching and learning initiative within one Māori-medium ITE programme. ${ }^{3}$ Funded by Ako Aotearoa, the project aimed to build upon existing teaching and learning strategies to improve academic outcomes in an undergraduate degree level Māori-medium ITE programme. Using a kaupapa Māori approach to methodology (Pihama, 2010; Smith, 1997), the project was led by a Māori research team, and primarily sought to address the needs of Māori students and staff within the programme. Research activities included: an online student survey; statistical analysis of student results; focus group student interviews; individual staff interviews; staff hui; and student hui. For the purposes of this article, the student data have been utilised, in particular the online survey (84 participants) and focus group student interviews undertaken with 24 students (years 1, 2 and 3). As with Te Matatini, although attention is on the stage, there is just as much interest in what is going on behind the scenes. Building on previous work by Hōhepa et al. (2014), this study adds another layer of students' voices in order to understand more clearly language related issues and student experiences in Māori-medium ITE programmes. The article presents some of the complexities associated with Māori language

\footnotetext{
${ }^{1}$ Principal Research Analyst, Tertiary Sector Performance Analysis, Ministry of Education.

${ }^{2}$ Four key components - Curriculum knowledge and teaching, Education studies, Te reo me ngā tīkanga, and Practicum - must be included in all programmes; however, other components, such as second language acquisition pedagogy, are taught in some programmes and not in others (Murphy et al., 2008).

${ }^{3}$ See Lee-Morgan, J. (forthcoming). Taikākāa: Optimising Māori medium education in a tertiary education programme. Wellington: Ako Aotearoa.
} 
regeneration facing students of Māori-medium ITE framed by the socio-historical and political contexts.

\section{Setting the stage: Māori language revitalisation}

To appreciate what or who is on the stage, or even the stage itself, Māori-medium ITE must be viewed within the wider context of Māori education in Aotearoa. Māori-medium ITE can be seen as part of both the Māori education and Māori language revitalisation movements. Like other Indigenous peoples, our experiences (including education) are characterised by the impact and processes of colonisation. Up until the 1860s, Māori was the language of communication across all domains (Higgins \& Keane, 2015a). It was also the language of the majority in interactions with non-Māori in the areas of trade and economics, as well as cultural and religious exchanges (Simon \& Smith, 2001). While the early missionaries began what can be considered the first Māori-medium western styled schools 200 years ago (Hōhepa et al., 2014), their intent was to 'civilise' Māori communities through Christianity (Simon \& Smith, 2001).

Increased and purposeful involvement in schooling by the state saw an explicit agenda of assimilation, implemented through a number of legislative processes including the Native Schools Act in 1867. Subsequently, government-led policies determined that the language of instruction in Native Schools shift from Māori (medium in the early missionary schools) to English. Corporal punishment of children caught speaking Māori in the playground ensured that English was not only the official expectation, but it became the cultural norm in schools (Walker, 1990). Exclusionary 'educational' practices that denigrated the status of Māori language and culture, and subsequently the health and corpus of the language, became most evident in the Māori language survey conducted from 1973 to 1979. Led by Dr Richard Benton, the survey revealed a drastic decline in the numbers of Māori students who could speak Māori (Benton, 1979). Whereas in 1913 90\% of students were able to converse fluently in the Māori language, this figure had dropped to 26\% by 1953 (Waitangi Tribunal, 1986). Less than thirty years later, Benton's language survey showed that this number was smaller than 5\% (Benton, 1979).

By the mid-1970s, a groundswell of Māori-led activism was gathering momentum, many of these activists motivated by passion and a growing concern to protect the language. One of the first Māori initiatives was the creation of Te Kōhanga Reo, a Māori-medium approach to the regeneration of the language for pre-school children. Three years after the opening of the first kōhanga reo in 1982, the number had grown to nearly 400, and by 1987 there were 512 kōhanga reo throughout the country (Waitangi Tribunal, 2012). ${ }^{4}$ The explosive growth in this kaupapa Māori initiative, which led to the development of kura kaupapa Māori and wharekura, was driven by Māori whānau and communities (Higgins \& Keane, 2015b; Tangaere, 2012; Waitangi Tribunal, 2011). Furthermore, the creation of an alternative kaupapa Māori education system through the medium of Māori had a major effect in reinvigorating the health of the Mãori language.

Today Māori-medium schooling includes kura kaupapa Māori as well as any classes, units and schools where students are taught all or some curriculum subjects in the Māori

\footnotetext{
${ }^{4}$ Today there are over 460 kōhanga reo operating around the country (Te Kōhanga Reo National Trust, 2016).
} 
language for at least $51 \%$ of the time (Education Counts, 2016). The Māori-medium sector is still small with only $2.3 \%$ of Māori students enrolled in this pathway at the primary and secondary school level (Education Counts, 2016). However, Māori-medium education, of which Māori-medium ITE is a part, is still considered a critical player by whānau and communities in the continued drive for cultural and linguistic regeneration (Cram, Kennedy, Kelly-Hepi Te Huia, \& Paipa, 2012). Furthermore, it is now an important part of the educational landscape, with the stage set attentively on the development of Māori language policies.

\section{Te reo Māori policies}

In 1986, the Treaty of Waitangi WAI 11 claim recognised te reo Māori as a taonga (treasure), whose protection is guaranteed by the Treaty of Waitangi (Waitangi Tribunal, 1986). The following year te reo Māori was bestowed as an official language of Aotearoa (Higgins \& Keane, 2005c). Despite these successful political manoeuvres, Māori language revitalisation efforts and the emergence of Māori-medium education, the ongoing impact of colonisation continues to render te reo Māori to be in a tenuous position. According to Statistics New Zealand, only $11 \%$ of Māori adults are able to speak te reo Māori very well or well (Statistics New Zealand, 2014). To assist in the recovery of the Māori language, numerous policies, reports and strategies have been developed to preserve it and to achieve a critical mass of speakers (Te Puni Kōkiri, 2011). In brief, there are some key intersecting policy developments that are relevant here to understand the importance of the Māori language, including the role of Māori-medium ITE.

In 2003, The Māori Language Strategy (Te Puni Kōkiri, 2003) was released following a series of hui with Māori communities. Based in part on the findings of the 5,000 people surveyed about Māori language, The Health of the Māori Language in 2001 (Te Puni Kōkiri, 2002) and the Māori language strategy (Te Puni Kōkiri, 2003) emphasised normalising the use of the Māori language in the home and community, and identified five interrelated goals. Goal 3 specifically relates to strengthening education opportunities in the Māori language, proposing that "by 2028 all Māori would have enhanced access to high-quality Māori language education" (Te Puni Kōkiri, 2002, p. 23). In 2010, the Minister of Māori Affairs established an independent panel, Te Paepae Motuhake, to inquire further into the state of the Māori language and this panel produced the report Te Reo Mauriora 2011, a review of the Māori language sector and the Te Rautaki Reo Māori: Māori Language Strategy (Te Puni Kōkiri, 2014). In the same year, the Waitangi Tribunal released a report of the WAI 262 claim, Ko Aotearoa Ténei (Waitangi Tribunal, 2011). Collectively, these reports and reviews reinforce that the Māori language was still at risk, and demanded for (amongst other things) iwi leadership in language revitalisation, the need to improve relationships between government, iwi and Māori, and the importance of supporting whānau, community and iwi language growth and development. As a result a new Māori Language Strategy was developed.

The Māori Language Strategy 2014 (Te Puni Kōkiri, 2014) highlights the New Zealand government's commitment to strengthening educational opportunities in te reo Māori for both Māori and non-Māori students. In particular, the strategy confirms the role of lead governmental agencies, including the Ministry of Education, in supporting the revitalisation of the Māori language. Te Taura Whiri i te Reo Māori is tasked with monitoring and evaluating these agencies, programmes and services (Te Puni Kōkiri, 2014). The newly formed Te 
Mātāwai, an independent statutory entity responsible for leading the revitalisation of te reo on behalf of iwi and Māori, is the legislative result of the bilingual bill, Te Ture mō te Reo Māori 2016 - The Māori Language Act 2016 (Te Puni Kōkiri, 2016). Te Mātāwai confirms the role of iwi and Māori as kaitiaki (guardians) of the language who will work with Crown agencies, again including the Ministry of Education, on Māori language strategies to increase uptake and fluency in the Māori language.

In the education sector itself, a number of policies have also been developed to support te reo Māori as well as the continued focus to improve Māori educational outcomes. For instance, Ka Hikitia: The Māori Education Strategy 2008-2012 (Ministry of Education, 2008) emphasised the need to improve te reo Māori teaching across the entire education sector. $\mathrm{Ng} \bar{a}$ Haeata Mātauranga: The Annual Report on Māori Education 2008/09 (Ministry of Education, 2009) echoed the same sentiment, adding the need to address the shortage of high-quality Māori-medium teaching and resources. This report cited two key goals in the area of Māori Language in Education: to increase the number of quality Māori teachers proficient in te reo Māori; and to increase effective teaching and learning of and through te reo Māori (Ministry of Education, 2009). The latter aligns with Indigenous peoples' fundamental human rights, as set out in the United Nations Declaration on the Rights of Indigenous Peoples 2007, to speak, teach and learn their own languages (United Nations, 2008). In 2013, the Ministry of Education released Tau Mai Te Reo, the Māori Language in Education Strategy 2013-2017 (Ministry of Education, 2013b), specifically aimed at strengthening the quality and prominence of te reo Māori in education. Building on the two previously mentioned documents, Tau Mai Te Reo acknowledges the role of ITE with an emphasis on increasing the enrolment and completion of students in Māori-medium ITE. Furthermore, the Strategy recognises the importance of this sector, stating "initial teacher education, particularly for Māori-medium education professionals, contributes to better outcomes for Māori language learners by raising the quality of Māori language teaching and learning" (p.10). These policy documents evidence the responsibility of the Ministry of Education to supporting Māori language and the significance of Māori medium ITE.

The Graduating Teacher Standards (GTS) (Education Council of New Zealand, 2008a), on the other hand, make no specific mention of Māori-medium ITE graduates, instead collapsing Māori medium together with English medium ITE. While the Standards have also been translated into te reo Māori, they are essentially the same (Education Council of New Zealand, 2008b). Murphy et al. (2008), in their study of Māori-medium ITE providers, found differences and uniqueness to the Māori ITE programmes' principles and foundations, and that in comparison to the GTS, these are influenced by a variety of factors "including Māori conceptual frameworks, the role of iwi and tikanga and international research" (p. 16). Cram and colleagues (2012), in their background papers for the Ministry of Education on Māori-medium ITE outcomes, ${ }^{5}$ set out an optimal graduate profile for Māori-medium ITE. The expectation is not just a graduate who is competent in te reo Māori, curriculum and pedagogy, but rather, the six key principles of kaupapa Māori identified by Graham Hingangaroa Smith (1997). These principles are: Tino Rangatiratanga - including knowledge about and commitment to Māori self-determination; Taonga Tuku Iho- understanding one's own identity, language and culture, being open to Māori knowledge and expertise and the role that culture plays in education, and an understanding of the centrality of te reo Māori to Māori cultural aspirations; Ako Māori -

\footnotetext{
${ }^{5}$ Graduate Profile \& Effective Practicum and Induction Experience.
} 
understanding and implementing in the classroom a Māori culturally preferred pedagogy; Kia Piki Ake i Ngā Raruraru o te Kāinga - the ability to confront the deep-seated and deficit-based assumptions about Māori student learning and success; Whānau - including an ability to build caring and respectful relationships with students, whānau, community, hapū and iwi; and Kaupapa - understanding the historical context of Māori-medium education, including knowledge of, and commitment to, its underlying philosophies (as cited by Cram et al., 2012). Cram and colleagues (2012) advocate a "holistic profile that interweaves cultural expertise and teaching expertise to create a picture of a quality, professional Māori-medium ITE graduate" ( $p$. 64). According to Cram et al., Māori-medium ITE graduates need to be committed to teaching and learning within the context of the vision of Māori-medium education, and have a heartfelt desire to see Māori-medium education persevere and succeed. Given the socio-historical context in which Māori-medium education has emerged as a site for reclamation of Māori language, culture and power, there are great expectations of Māori-medium ITE students. It is envisaged that these students will be key to the regeneration of not only the Māori language, but also cultural knowledge and practices, as well as conventional measures of educational success.

\section{Backstage: Māori-medium ITE student voices}

While Māori-medium ITE is poised as an important character on the Māori language education stage, Māori-medium ITE students' voices provide an important insight into what goes on backstage. As Skerrett (2011) and Hōhepa et al. (2014) have argued, te reo Māori in a tertiary immersion environment can be a complex and challenging undertaking for many Māori-medium ITE students. Despite the intention of language and education policies, when the spotlight shifts behind the scenes, the realities that face Māori-medium ITE students are revealed.

The student research cohort that informs this study was made up of 84 participants, $90 \%$ of the students in the particular programme that was the focus for the project. All of these students were enrolled in a Bachelor's degree in primary education (Māori medium) across two campuses, the main urban campus with 52 students $(61.9 \%)$, and a smaller satellite campus with $26(31.0 \%)$. The demographic of this cohort is consistent with the national characteristics of Māori-medium ITE students; in general they are mainly Māori, with a higher proportion of mature students and women, and they are mostly second language learners (Murphy et al., 2008; W Smart, personal communication, March 21, 2017). In our research cohort $58.4 \%$ of the students were aged over 25 years, ${ }^{6} 70 \%$ were female, and $93 \%$ identified themselves as Māori. ${ }^{7}$

One of the dominant characteristics of these students was their collective inspiration to actively reclaim the Māori language, which is the primary motivation behind the majority

6 The estimated mean age was 29.7 years old, whereas the mean age of their 920 student counterparts enrolled in the English medium BEd primary programme at the start of 2015 was 24.9.

7 Students were able to select any number of ethnicities with whom they identified as a member. Overall, 93\% of the cohort (78 participants) identified themselves as Māori (and another group), 15 participants (18\%) identified themselves as being Pākehā, five (6\%) as Samoan, five (6\%) as Cook Islander, three as Niuean, one as Tongan, one as Chinese, and five (6\%) as Other. 
of students who commit to pursue working in Māori-medium education. When students were asked (in an open-ended question) in the online survey about the reasons why they had enrolled in the Māori-medium ITE programme, aligned to the previously mentioned kaupapa Māori language education initiatives, the top reason for enrolment was te reo Māori. The opportunity to learn and/or strengthen their te reo, tikanga and Māori identity (34 responses) outweighed the (second top) reason, to become a teacher (28 responses). For many students, the aspiration to learn te reo Māori was not seen as an individual or academic pursuit, but one that was borne from a desire to reconnect to cultural knowledge and practices, to reclaim identity, and enhance the wellbeing of whānau and future generations. One student said:

It wasn't until I had my first child that I wanted to learn te reo. It sort of occurred to me that it would be the third generation in our family that wouldn't have the reo and it would probably be lost forever within our family. So I went to ... a rumaki reo (immersion language) course and learnt te reo ... It became my passion, and I saw the opportunity to become a teacher where I could use the reo. ( $3^{\text {rd }}$ Year Student, Satellite campus)

Reflecting a key concept of ako (Māori pedagogy), the opportunity to learn te reo Māori was integral to (learning to) teach te reo, and in doing so contribute to language regeneration. The responsibility to teach te reo, part of the reciprocal nature and cultural conditions of ako (Lee, 2008), was reflected in the third top reason for enrolling in the programme, to 'contribute back to their community' (21 responses). Te reo Māori as the key driver for selecting a Māori-medium teacher education pathway was echoed in the focus group interviews and student hui, and Māori language regeneration could be enacted in their own whānau, and teaching in their hapū, iwi and/or communities.

Consistent with the research literature on Māori-medium ITE students, a passionate commitment to the regeneration and intergenerational transmission of te reo Māori was a recurring theme. Hōhepa and colleagues' (2014) case study of four institutions providing Māori-medium ITE programmes in Aotearoa also found that Māori-medium students in ITE expressed their passionate commitment to: the survival of te reo Māori and tikanga Māori; contributing to the kura kaupapa Māori context; contributing to their community, hapū, and iwi; their personal development of te reo Māori and tikanga; and making positive differences to children's learning in kura and Māori-medium settings. The reclamation of Māori language and culture, at the heart of students' aspirations, was intimately tied to the quest to achieve in education for their whānau. One student explained:

I really want to do this, and it's something I've wanted to do for a long time ... there's no high achievers in my whānau and I want to be that leader for our whānau. ( $1^{\text {st }}$ Year Student, Satellite campus)

Students aspired to take a leadership role within their whānau and be Māori language role models in terms of pursuing higher education. Their goal was one of being able, as teachers, to make a difference to Māori students, whānau and communities through the sustenance and development of te reo, tikanga and mātauranga Māori. The goal to 'live as Māori' (Durie, 2001; Ministry of Education, 2007) is enacted by these students through their desire to learn, teach, and live te reo Māori.

Given the opportunity to strengthen te reo and tikanga Māori was likely to be the key driver for most students entering the Māori-medium ITE pathway, it is not surprising that the variability of Māori language proficiency was identified as a significant issue. Students 
identified that there had been few opportunities to participate in an immersion type of learning environment to advance their own Māori language and cultural competence, and deepen their knowledge and understanding of mātauranga Māori (Māori knowledge systems). For some students, Māori-medium ITE provided an opportunity to simultaneously learn the Māori language, with the aim of teaching through the medium of the Māori language.

While all students were required to meet particular entry criteria for this institution, students with (self-identified) lower levels of Māori language proficiency understandably struggled. These students found it more difficult to comprehend and respond to instructions in the immersion environment of their courses, to the extent that some felt overwhelmed. One student explained:

It [te reo Māori] has gradually grown but not to the [extent] where I would have loved it to have been in the third year. So ... for me it's hard to sit there and be part of a tutorial that is in te reo Māori. Firstly, l've got to try and break down what they are actually talking about. Secondly, l've got to try and adjust to the university language that everyone speaks about. And then, by the time I have comprehended some of what is said, it's hard for me to write down the notes and reflect on the lessons that have [already] gone. So it's a struggle. I am probably at the bottom end of where we would be in our class for the proficiency of te reo Māori and that takes a knock as well, just with everything that you do, compared to the English papers. The English papers are a lot easier because I can understand, I can comprehend and I can adjust, whereas te reo Māori it's quite hard, especially if you are directed a question in te reo Māori and you are expected to answer in te reo Māori. And you are sitting there like, 'Um, why did you ask me!?' And you try and avoid it at all costs. (3rd Year student, Main campus)

Although students had attained a level of te reo Māori proficiency, some felt it was not enough to be able to sustain their learning within the programme. The above student's comments also signal the complexity of the challenge that affects one's level of confidence as a Māori learner. Whakamā (feelings of embarrassment or shame), for instance, was a major factor inhibiting some students from advancing their Māori language proficiency. Also identified by Skerrett (2011), whakamā was a major barrier for learners of Māori owing to the close connection between language and identity and the resulting fear of failure.

These students felt that they were less likely to speak te reo in the presence of their tutors and lecturers for fear of making mistakes and being corrected. One student said:

For myself, what I find difficult about speaking te reo is that I don't do it as much as I would like to. Even when I come to uni, ka huri ahau i roto i te reo Pākehā i roto i ngā kauhau (I turn to using English in the lectures), and I think that's because when I know that the lecturer is listening and if I get any kupu (words) wrong, ka tini ngā hapa (I make many mistakes), and I'm like, 'Oh they might point that out.' And yet when I'm on practicums, like in my first year, my second year, the flow of my reo just flows out instantly kei roto i ngā ruma (in the classroom). But when I feel that there's a watchful eye over me, I don't know, with someone that I know he mōhio ki te kōrero, (knows how to speak Māori) I kind of huri ki te reo Pākehā (turn to speak English). And I think that's my real difficulty in relation to my reo. (3rd Year student, Satellite campus)

In situations where students experienced less or no anxiety about 'getting it wrong', they found their reo flowed more readily and naturally. Whakamā, in relation to Māori language, 
is not just about an individual's lack of language skills and abilities; whakamā here invokes deeper feelings that often involve historical whānau language loss and issues of identity and belonging. As the research by Hōhepa and colleagues (2014) suggests, Māori language proficiency as a Māori-medium ITE learner is complex.

Lower levels of language proficiency were exacerbated for students by the realisation that there was not time within the programme itself to adequately address their language development needs. The students stated:

I think it's incredibly challenging, even though I did reasonably well learning te reo in 2007. Down to little things like how to say in Mathematics, that 8 is larger than 3 , getting the ' $i$ ' and the ' $k i$ ' in the right place. And the time given in the course I think is limited in terms of accessing that information. And it's also not the focus, the focus is on getting the degree in Education rather than getting a degree in te reo, and the reality within my generation is they aren't first language speakers. ( $3^{\text {rd }}$ Year student, Satellite campus)

The grammatical side doesn't help if you don't know what the English grammar is, let alone what it's meant to be in Māori. It's almost like you need a separate class to build that reo and to build that understanding why you have to learn grammar. We actually haven't been told why we need to learn it. We sort of know [it's] because we have to teach it when we go out as teachers, but we haven't been told you have to learn this. There's nothing in concrete. ( $2^{\text {nd }}$ Year student, Main campus)

Even if language was specifically taught, some students felt that grammatical and linguistic approaches to language teaching presented barriers to students' fluency and confidence to converse. The students also expressed some confusion about whether or not there was an expectation that teaching through the medium of Māori in schools also included teaching the Māori language itself to students. The level of te reo Māori proficiency required for study posed multiple and complex everyday challenges, not just in the academic context but the school setting itself, where students were preparing to teach.

While the students understood that the onus was on themselves to increase their reo Māori proficiency, for those living away from their whānau, tribal areas and support networks, they were heavily reliant on local sources of fluent Māori language. For many students, accessing appropriate Māori language support was difficult:

I know a lot of it's on our own backs to improve our reo, but for some of us we don't have ... I live nine hours away to go home. I can't afford financially to go home to be surrounded by my own reo. For some that are urban Māori, they don't have the luxury of having our older people and our whānau around to kōrero Māori. ( $2^{\text {nd }}$ Year student, Main campus)

Where do I, or can I find someone, anyone, on our campus that I can have regular discussions with in Māori and who isn't a lecturer? Or someone neutral that can critique what I've written? Or someone to bounce off when I need to have a conversation in te reo that's above kōhanga or kura tuatahi (primary) level of te reo Māori, in order for me to grow and learn more? Finding someone above my level and ability to input that info often and willingly is really hard to find. ( $3^{\text {rd }}$ Year student, Main campus)

The students' comments indicate that some are living away from their homes and/or tribal communities, and that it is not easy to regularly return to those who would normally support them with their language learning. These students often find it difficult to not only find Māori speakers to converse with, but appropriate people who are able to support the development 
of their language proficiency in relation to teacher education at a tertiary level, in other words, to assist with their academic literacy (in Māori).

Shifting from an everyday Māori language (and understandings) to academic language (and theories) was a further complication for students. Simply stated, one student said:

Because my level of te reo is not as strong as my level of English is, academic learning in te reo is going to be more difficult ... than learning in English. ( $1^{\text {st }}$ Year student, Main campus)

Unsurprisingly, the online survey data clearly showed that most students felt more confident in English (in class speaking, reading, assessment completion, essay writing, academic preparedness and critical thinking) than each of these things in Māori. The students reported that they felt the least confident in academic reading and essay writing in Māori, two of the key academic measures in the programme. One approach suggested by Skerrett (2011), in her literature review of factors likely to influence Māori language proficiency of Māorimedium ITE graduates, is to support students who come into Māori-medium ITE programmes with low levels of Māori language proficiency by introducing a four or five-year Māorimedium ITE programme that includes a minimum of a one-year full-time immersion Māori language course prior to beginning the ITE programme.

Echoing the literature about student experiences in Māori-medium ITE (Hōhepa et al., 2014), even the students who identified themselves as more fluent in te reo Māori still struggled with the academic Māori language demands of the programme:

The language and the level of language can be totally overwhelming; the vocab and the way the subjects are delivered from lecturer to lecturer are totally different, both in Māori and English. Academic English was foreign to me when I started here - so the whole process of understanding complex texts and subjects such as diversity or education psychology, and even language acquisition, I think is more of a challenge in Māori. ( $3^{\text {rd }}$ Year student, Main campus)

Academic Māori language expectations (i.e., writing essays in an academic Māori genre), combined with specialised curriculum words in te reo Māori, posed continual te reo Māori challenges. One student pointed out the critical role of their lecturers in this situation:

A lot of stuff that we learnt was quite hard. It's a whole new [specialist] reo on top of the reo we are already learning, and [the teacher] simplifies everything. He talks to us like normal people, doesn't use all these big flash words or [anything] like that. He breaks it all down so that we have a good clear understanding of everything. And he's very open, so you're not afraid to ask him questions - as opposed to the other lecturers where you kind of sit there and feel like ... if I ask, I'm going to look like the dummy. ( $2^{\text {nd }}$ Year student, Main campus)

Modelling ako and effective Māori language teaching and learning strategies in the classroom was pivotal to creating conditions for success. Just as other research has found, the ability of the teacher to provide clear instructions, expectations, and explanations was critical for students studying in Māori and English (McDowall, 2015; Murphy et al., 2008; Skerrett, 2011).

Upskilling for Māori-medium ITE students usually took place outside of lectures as part of the initiatives run by the Academic Māori Student Support Services. Many students highly valued the student support initiatives provided, and were quick to acknowledge the work of 
Māori support services staff, and in particular, the strong relationships that they had developed with students, and the positive environment they had created for learning. Many students believed that these initiatives were a key factor in the retention of students in the programme. Students explained:

To be in an environment where you can bounce your ideas off and ask questions without that whakamā, and to see people who aren't specialists in their field still being able to help you ... without wānanga there probably wouldn't have been much of a success rate for $[X]$ in our class. Actually some of those who are not here in Year 2 are the ones who didn't come to wānanga, all of them, I think, didn't attend any of our wānanga. (2nd Year student, Main Campus)

I've submitted most of my assignments to date in te reo Māori and only a few in English, to balance out and to assess my own ability to write in both languages ... A follow-up like a workshop [wānanga] to address the gaps in my Māori academic writing would be fantastic, if ever an opportunity comes up before the end of this year to do so, as I don't think I hit the mark, or I deviated from what I should be saying. (3rd Year student, Main campus)

Customised wānanga and Māori academic support initiatives played an important role in the perseverance of students to complete their courses despite the challenges. As with the findings of Curtis et al. (2012), culturally appropriate support, whether it be academic, pastoral or learning environments, was key to Māori student success at the tertiary level. The current trend to disestablish specialist Māori positions and services, such as academic support services in tertiary institutes, termed 'whitestreaming' (Potter \& Cooper, 2016), is of major concern to Māori-medium ITE programmes. In mainstream tertiary institutions where English language and cultural practices are the norm, specialist Māori academic support roles that respond to the learning needs of Māori students and encourage a greater sense of belonging are hugely significant for Māori-medium ITE students:

Pou Whirinaki (mentors) have gone through the years, and their experience means that that they can draw out of you what is required. With $[X]$ and the engagement that we get into groups, we create learning styles, learning techniques that will help us remember, recall information for exams and for assignments - just with the writing techniques, the note taking techniques, the essay writing. That was huge when we realised in an exam last year or in a lecture last year that in the Year 2 mainstream, they are still having problems that should have been resolved in Year 1. But because we had the advantage of doing the wānanga, we were way past that in regards to essay writing. (3rd Year student, Epsom campus)

As Hōhepa, et al. (2014) and Murphy et al. (2008) found, Māori-medium ITE programme providers require a range of support systems in order to successfully develop students' Māori language proficiency and pedagogical knowledge and skills.

\section{Conclusion}

For many reasons, the metaphor of the stage was selected to frame the discussion of Māorimedium ITE. Firstly, this was because the stage, like Māori-medium ITE, is a complex space. 
By listening to the students' voices, we find the opportunity to strengthen Māori language is both the motivation and inspiration for most students. Ironically, however, it also becomes the students' greatest challenge to success. Similarly, schooling as a tool of colonisation also becomes a site of reclamation and space to forward kaupapa Māori educational initiatives. Whatever appears on the stage is always part of a greater narrative; as in the case of Māorimedium ITE, the broader story is about Māori language. The way the language was demonised and efforts to recover it are evident in the students' aspirations for, and struggle in, te reo Māori.

Purposefully avoiding a pathological approach to viewing Māori-medium ITE, the metaphorical use of the stage seeks to make visible the conviction of Māori-medium ITE students, as well as the complexities they face in their ITE programmes. Making visible the realities of students in Māori-medium ITE, as it relates to Māori language, reminds us that Māori is not just another language, but an Indigenous language that is at the heart of Māori identity. Like other Indigenous languages, it is still highly susceptible to colonising conditions, and the space that has been claimed in mainstream institutions such as universities is always tenuous. What has been out of the purview in this article, but always omnipresent when analysing kaupapa Māori initiatives within mainstream institutions, is the structure within which Māori-medium ITE is located. To return to the image of the stage, and critically look at the stage itself, is to see not a neutral, apolitical space, or to use a common phrase, not a 'level playing field'. Despite the aforementioned policies that recognise the centrality of the Māori language and the role of Māori-medium ITE, the political and institutional structures determine the ways in which the Māori-medium qualifications, and therefore programmes, are set, influence pedagogy and impact on how staff and students engage in the programme itself. For example, Skerrett's (2011) recommendation to explore a different ITE model that takes into account variable levels of language proficiency responds to the structural constraints.

Similarly, Māori student support services are critical, and institutional trends such as whitestreaming must be addressed to ensure the success of Māori-medium ITE students in and beyond their ITE programmes, as Māori teachers. The voices of Māori-medium ITE students highlight the complex realities between (what might be considered) aspirational Māori language and education policies and the actual provision of Māori-medium ITE, in particular, students' experiences. Implications for policy include better alignment of intersecting Māori language and Māori-medium ITE. This requires the activation of policies in practice that take into account the on-going impact of colonisation and challenges of language regeneration that demand a disruption to conventional ITE programmes and practices, including curriculum, assessment measures, academic support and resourcing.

It is clear that Māori-medium education originates from kaupapa Māori drivers that aspire to recover language and culture as part of social transformation. In this regard, Māori medium teachers are not simply expected to deliver conventional 'education' through the medium of the Māori language. Rather, as Cram et al. (2012) propose, Māori-medium ITE graduates are more like cultural ambassadors with expertise that is highly valued by whānau, communities, and schools alike. Endorsed by Māori language and educational policies, high hopes are pinned to Māori-medium teachers. Like the excitement of the Matatini, all eyes are on the stage to see whether or not all the practice behind the scenes (and policies) will pay off. Has Māori medium ITE had the ability to fully prepare their graduates to perform successfully in schools, and effectively serve the learners and their whānau? Will the students' language proficiency enhance or impede teaching and learning? Can Māori-medium ITE 
graduates fulfil the hopes to regenerate the Māori language and culture, and in doing so reinvigorate Māori education? If so, Māori-medium ITE's performance will radiate on stage, positively educating through the beauty and depth of te reo, tikanga and mātauranga Māori - and even impacting the resolute mainstream audience watching from afar.

\section{References}

Benton, R. (1979). Sociolinguistic survey of language use in Māori households: Notes on the purposes and methodology of the survey. Wellington, NZ: New Zealand Council for Educational Research.

Cram, F., Kennedy, V., Kelly-Hepi Te Huia, M., \& Paipa, K. (2012). Background papers: Māorimedium initial teacher education outcomes: Graduate profile \& effective practicum and induction experiences. Auckland, NZ: Katoa.

Curtis, E. T., Wikaire, E., Lualua-Aati, T., Kool, B., Nepia, W., Ruka, M., ... Poole, P. (2012). Tātou tātou/success for all: Improving Māori student success (Research report). Wellington, NZ: Ako Aotearoa National Centre for Tertiary Teaching Excellence.

Durie, M. (2001). A framework for considering Māori educational advancement. Opening address at Hui Taumata Mātauranga, Taupo, NZ.

Education Council of New Zealand. (2008a). Graduating teacher standards. Retrieved from https://educationcouncil.org.nz/sites/default/files/gts-poster.pdf

Education Council of New Zealand. (2008b). Ngā Paerewa Pouako Paetahi. Retrieved from https://educationcouncil.org.nz/sites/default/files/gts-poster-Māori.pdf

Education Counts. (2016). Māori language in education: Māori-medium. Retrieved from http://www.educationcounts.govt.nz/statistics/Māori-education/Māori inschooling/6040

Higgins, R., \& Keane, B. (2015a). Te reo Māori - The Māori language: The spread of English, 1840s to 1900. Te Ara: The Encyclopedia of New Zealand. Retrieved from http://www.TeAra.govt.nz/en/te-reo-Māori-the-Māori-language/page-3

Higgins, R., \& Keane, B. (2015b). Te reo Māori - The Māori language: Ongoing work, 1980s to 2000s. Te Ara: The Encyclopedia of New Zealand. Retrieved from http://www.teara.govt.nz/en/te-reo-Māori-the-Māori-language/page-6

Higgins, R., \& Keane, B. (2015c). Te reo Māori - the Māori language. Te Ara: The Encyclopedia of New Zealand. Retrieved from http://www.TeAra.govt.nz/ en/te-reo-Māori-the-Māori-language

Hōhepa, M., Hāwea, N., Tamatea, K., \& Heaton, S. (2014). Te Puni Rumaki: Strengthening the preparation, capability and retention of Māori-medium teacher trainees (Final Report). Wellington, NZ: Ministry of Education.

Lee, J. (2008). Ako: Pūrākau of Māori teachers' work in secondary schools (Unpublished PhD thesis). University of Auckland, New Zealand.

McDowall, S. (2015). Literacy research that matters: A review of the school sector and ECE literacy projects. Wellington, NZ: New Zealand Council for Educational Research.

May, S., \& Hill, R. (2005). Māori-medium education: Current issues and challenges. International Journal of Bilingual Education and Bilingualism, 8(5), 377-403.

Ministry of Education. (2007). Tertiary education strategy 2007-12. Wellington, NZ: Author. Ministry of Education. (2008). Ka Hikitia: Managing for success/Māori education strategy 2008-2012. Wellington, NZ: Author. 
Ministry of Education. (2009). Ngā Haeata Mātauranga: The annual report on Māori education 2008/09. Wellington, NZ: Author.

Ministry of Education. (2013a). Ka Hikitia: Accelerating success 2013-2017: The Māori education strategy. Wellington, NZ: Author.

Ministry of Education. (2013b). Tau Mai te Reo: The Māori language in education strategy 2013-2017. Wellington, NZ: Author.

Murphy, H., McKinley, S., \& Bright, N. (2008). Whakamanahia te reo Māori: He tirohanga hōtaka - an exploration of issues and influences that effect Te Reo Māori competence of graduates from Māori-medium ITE programmes. Wellington, NZ: New Zealand Teachers Council.

Pihama, L. (2010). Kaupapa Māori theory: Transforming theory in Aotearoa. He Pukenga Kōrero: A Journal of Māori Studies, 9(2), 5-14.

Potter, H., \& Cooper, L. (2016). Project whitestreaming: A report on the generalising of Māori specialist staff positions in the tertiary education sector. Prepared for the Tertiary Education Union Te Hautū Kahurangi o Aotearoa, Wellington, NZ. Retrieved from http://teu.ac.nz/wp-content/uploads/2016/03/20160314-

Project-Whitestreaming-Report-FINAL.pdf

Simon, J., \& Smith, L. (Eds.). (2001). A civilising mission? Perceptions and representations of the New Zealand native schools system. Auckland, NZ: Auckland University Press.

Skerrett, M. (2011). Whakamanahia te reo Māori: He tirohanga rangahau: A review of the literature with relevance for te reo Māori competence of graduates from Māorimedium initial teacher education programmes. Wellington, NZ: New Zealand Teachers Council.

Smith, G. (1997). The development of Kaupapa Māori: Theory and praxis (Unpublished PhD thesis). University of Auckland, NZ.

Statistics New Zealand. (2014). Te Kupenga 2013 (English) - corrected. Key facts. Retrieved from

http://www.stats.govt.nz/browse_for_stats/people_and_communities/maori/TeKup enga_HOTP13.aspx

Tangaere, A. (2012). Te Hokinga ki te Ūkaipō. A socio-cultural construction of Māori language development: Kōhanga Reo and home (Unpublished PhD thesis). University of Auckland, NZ.

Te Kōhanga Reo National Trust. (2016). History. Retrieved from http://www.kohanga.ac.nz/history/

Te Puni Kōkiri. (2002). The health of the Māori language in 2001. Wellington: Author.

Te Puni Kōkiri. (2003). He Rautaki Reo Māori: The Māori language strategy. Wellington, NZ: Author.

Te Puni Kōkiri. (2011). Te Reo Mauriora: Ministerial review of Māori language strategy and sector. Wellington, NZ: Author. Retrieved from http://www.tpk.govt.nz/documents/tereo-mauriora.pdf

Te Puni Kōkiri. (2014). Developing a new Māori language strategy. Wellington, NZ: Author.

Te Puni Kōkiri. (2016). Te Ture mō te reo Māori: The new Māori Language Act. Retrieved from https://www.tpk.govt.nz/en/a-matou-kaupapa/strengthening-Māori-culturalwealth/te-reo-Māori/

United Nations. (2008). United Nations declaration on the rights of Indigenous peoples. Retrieved from http://www.un.org/esa/socdev/unpfii/documents/DRIPS_en.pdf 
Waitangi Tribunal. (1986). Waitangi Tribunal report on the Te Reo Māori claim (WAI 11). Wellington, NZ: Department of Justice.

Waitangi Tribunal. (2011). Waitangi Tribunal Report 262 claim: Ko Aotearoa Ténei 2011. Wellington, NZ: Author.

Waitangi Tribunal. (2012). Waitangi Tribunal Report 2336: Matua Rautia-The Report on the Kōhanga Reo claim. Wellington, NZ: Author.

Walker, R. (1990). Ka whawhai tonu matou: Struggle without end. Auckland, NZ: Penguin.

\section{Authors}

Associate Professor Jenny Lee-Morgan (Waikato) has extensive experience and expertise in Māori Education as a whānau member, practitioner, academic and researcher. Formerly, Head of School, Te Puna Wānanga, The University of Auckland, she is currently the Deputy Director of Te Kotahi Research Institute at The University of Waikato. Her teaching and learning experiences were the impetus for much of her work, including her book Jade Taniwha: Māori-Chinese identity and schooling in Aotearoa and subsequent co-authored book Oho Ake: Rehu Marae, Ngā Puna o Waiōrea written in te reo Māori. Her most recent co-edited book is Decolonisation in Aotearoa: Education, Research and Practice. Jenny's doctoral thesis entitled 'Ako: Pūrākau of Māori secondary school teachers' (Lee, 2008) was seminal in the development of pūrākau as kaupapa Māori approach to narrative inquiry and sparked her investigation in pūrākau and indigenous story work.

Email: jennylm@waikato.ac.nz

Dr Maureen Muller (Ngā Puhi) is an academic researcher who completed her doctoral studies at Te Kawa a Māui, Victoria University in 2016. Her PhD thesis examined success factors that normalise the use of Māori language within the whānau. Maureen is a second language learner of te reo Māori which she acquired as a student of Te Ataarangi, one of the early Māori language revitalisation movements. She worked for Te Ataarangi in a number of roles including tutor, lecturer and research analyst. Now working independently, Maureen is extending her research capabilities through her engagement in a number of kaupapa Māori projects with other indigenous researchers.

Email: maureen.muller@xtra.co.nz 